\title{
IRRIGATION AND CONTAINER TYPE IMPACT RED MAPLE (ACER RUBRUM L.) 5 YEARS AFTER LANDSCAPE PLANTING
}

\author{
by Edward F. Gilman, Jason Grabosky, Ann Stodola, and Michael D. Marshall
}

\begin{abstract}
The objective of this research was to compare red maple (Acer rubrum L.) root and canopy growth 5 years after landscape planting from seven different container designs maintained under two irrigation regimes. Trees planted from low-profile air root-pruning containers had larger trunks 5 years after landscape installation than those planted from regular air root-pruning containers, wood boxes with cupric hydroxide coating, or standard black plastic containers with cupric hydroxide coating. Despite significant differences in root weight and amount of deflected roots among container types when trees were planted in the landscape, root number, root depth, and radial root distribution around the trunk were identical 5 years after planting from all container types. However, frequency of irrigation in the first 24 weeks following planting had a significant effect on root system structure even 5 years later. Frequent irrigation resulted in larger trunks, more roots, greater root cross-sectional area, and a more uniform radial root distribution. The increase in root growth on frequently irrigated trees occurred exclusively in the top $30.5 \mathrm{~cm}$ of soil. Codominant stems 4 years after planting were equally common, regardless of production method and irrigation treatment. With the exception of the low-profile air root-pruned container, the reduction in root defects on the outer surface of root balls grown in containers designed to reduce defects appeared to provide no measurable benefit to trees 5 months or 5 years after planting into the landscape. Irrigation management after planting had a more positive impact on landscape root growth and distribution than container type.
\end{abstract}

Key Words. Container production; air root pruning; chemical root control; deformed roots; transplanting; planting; root depth; root morphology; root modification; landscape.

Plants grown in standard plastic containers for too long often have deformed roots that are kinked or grow along the sides or bottom of the root ball. Many alternative container types have been designed to reduce the incidence of deformed roots. These options typically utilize one or more of the following: air root-pruning technology, special- ized container shapes, bottomless containers, nonwoven fabrics, mechanical deflection, or chemical manipulation (Brass et al. 1996; Marler and Willis 1996).

The type of nursery container used during production can have a dramatic impact on root morphology of container-grown plants (Arnold 1996; Gilman 2001). Copper compounds applied to the interior surface of plastic containers reduced root deflection on many woody species (Struve et al. 1994) and caused an increase (Beeson and Newton 1992), decrease (Arnold and Struve 1993), or no effect (Martin and Bhattacharya 1995) on root:shoot ratio. Roots in porous-walled plastic containers stopped growing when they reached the container wall-substrate interface (Privett and Hummel 1992). This resulted in less root circling compared to nonmanipulated root systems grown in standard containers (Gilman 2001; Marshall and Gilman 1998). Roots in square containers had fewer circling roots than those in standard round plastic containers (Warren and Blazich 1991).

Many studies on conifer seedlings show that root deflection in containers can contribute to long-term growth problems after planting in the forest (Nichols and Alm 1983). Young hardwood liners grown in alternative containers and transplanted to the landscape produced either more (Arnold 1996; Brass et al. 1996) or the same amount (Brass et al. 1996) of roots as trees raised in standard containers. Our past work showed that root and canopy growth were similar among \#15 container types 5 months after landscape planting (Marshall and Gilman 1998). The objective of this study was to compare root and canopy growth on the same group of trees 5 years after planting.

\section{MATERIALS AND METHODS}

In February 1995, red maple (Acer rubrum L.) 3.8 L seedling trees were planted in seven container types. The seven container types were (1) $66 \mathrm{~L}$ (\#15) standard black plastic container (SBPC), $41 \mathrm{~cm}$ diameter $\times 43 \mathrm{~cm}$ deep (Lerio Corp., Mobile, AL), (2) $66 \mathrm{~L}$ (\#15) SBPC treated on interior surfaces with $\mathrm{Cu}(\mathrm{OH})_{2}$ at a rate of $100 \mathrm{~g} / \mathrm{L}$ latex carrier (Spin Out ${ }^{\mathrm{TM}}$, Griffin Corp., Valdosta, GA), (3) low-profile black plastic container measuring $58 \mathrm{~cm}$ diameter $\times 33 \mathrm{~cm}$ deep (Lerio Corp.), (4) corrugated aluminum air root-pruning container (ARPC), $43 \mathrm{~cm}$ diameter $\times 41 \mathrm{~cm}$ deep (Accelerator, Hold-Em, Inc., West Palm Beach, FL), (5) low-profile corrugated 
aluminum ARPC, $56 \mathrm{~cm}$ diameter $\times 30 \mathrm{~cm}$ deep, (6) wooden, square container constructed of untreated pine, $42 \times 42 \times$ $42 \mathrm{~cm}$ (Ridge Pallets, Bartow, FL), and (7) wooden, square container treated on interior surfaces with Spin Out ${ }^{\mathrm{TM}}$ before planting. Each corrugated aluminum ARPC was perforated with holes of two types: round, $3.2 \mathrm{~mm}$ diameter; and rectangular, $6.3 \mathrm{~mm} \times 25.4 \mathrm{~mm}$, with rounded ends. ARPCs were bottomless and were placed on a nonwoven fabric cloth (style S700, 110 mil thickness, Hold-Em, Inc., West Palm Beach, FL).

After 70 weeks in production, the $3.9 \mathrm{~cm}$ caliper, $2.8 \mathrm{~m}$ tall trees were planted into a field in Gainesville, Florida, U.S., of well-drained Millhopper sand in USDA hardiness zone $8 \mathrm{~b}$ (average minimum temperature $11^{\circ} \mathrm{C}$, average maximum temperature $41^{\circ} \mathrm{C}$ ), as described in Marshall and Gilman (1998). Trees received one of two irrigation regimes, frequent or infrequent, for the first 24 weeks (May through October 1996) after planting. All trees were irrigated to saturation each day the first week after planting. On the frequent irrigation schedule, trees received $38 \mathrm{~L}$ of water daily during weeks 2 through 9 , then every other day during weeks 9 through 24. On the infrequent schedule, trees received $38 \mathrm{~L}$ of water once in weeks 2 and 3, every third day during weeks 4 through 9 , every 10 days during weeks 10 through 19 , then no irrigation. Water was applied to a $1 \mathrm{~m}$ diameter circle around the trunk. A scheduled irrigation was not applied if $6.3 \mathrm{~cm}$ or more of rain fell since the previous irrigation. No irrigation was applied October 1996 through April 1998. April 1998 began a 3-year dry period when rainfall was more than $127 \mathrm{~cm}$ below normal (normal annual rainfall is $132 \mathrm{~cm}$ ). From April 1998 through February 2001, all trees received $38 \mathrm{~L}$ of water three times per day four days per week during the growing season, and $41 \mathrm{~L}$ of water once per day three days per week during the dormant season. Water was applied to a $2 \mathrm{~m}$ diameter circle around the trunk. This was done to encourage vigor and was not needed for survival.

Fourteen trees from each of the two irrigation treatments ( 2 from each production method $\times 7$ production methods $\times 2$ irrigation treatments $=28$ trees) were measured for presence of codominant stems in fall 1999. Stems $2.54 \mathrm{~cm}$ and greater, measured $2.8 \mathrm{~m}$ from the soil, were recorded. Diameters were converted to cross-sectional area assuming a circular cross section. The number of stems greater than $75 \%$ of the area of the largest stem was recorded for each tree.

Thirty-five trees, five from each container type and 17 (frequent irrigation) and 18 (infrequent irrigation) from each of the two irrigation schedules, were harvested February 26, 2001, by digging the root balls with a $203 \mathrm{~cm}$ tree spade. Soil was washed from the root balls with highpressure water. The root systems were characterized by counting each root end larger than $9 \mathrm{~mm}$ in diameter that was cut by the blades of the tree spade and recording its diameter, depth in the root ball (distance from soil surface), and compass direction around the trunk to the nearest 5 degrees. The 360-degree circle around the trunk was divided into eight, 45-degree sections. Radial root distribution was measured by calculating the number of 45-degree sections without roots. Trunk caliper at $30.5 \mathrm{~cm}$ above the soil surface was also recorded.

Depth in the root ball was included as a factor in the analysis of root numbers and root cross-sectional area data. Two-way analysis of variance (ANOVA), with container type and depth in the root ball as factors, was performed using SAS general linear models procedure (SAS Institute 1992). Next, two-way ANOVA was performed with irrigation frequency and depth in the root ball as factors. Two-way ANOVA was performed with container type and irrigation frequency as factors. Means were compared using Duncan's multiple range test when the main effect was significant at the $5 \%$ level. The difference in the number of codominant stems for irrigation treatments and container types was compared with the t-test. Contrasts ( $5 \%$ level) were used to clarify the nature of interactions.

\section{RESULTS AND DISCUSSION}

There were no interactions between container type and irrigation. There was a significant effect of container type on trunk cross-sectional area 5 years after planting (Table 1). Despite being more stressed in the weeks following landscape installation (Marshall and Gilman 1998), trees planted from low-profile air root-pruning containers had larger trunks than those planted from regular air root-pruning containers, wood boxes with cupric hydroxide coating, or standard black plastic containers with cupric hydroxide coating. Trees planted from untreated wood boxes had greater trunk area than those from boxes with cupric hydroxide. Perhaps trees such as red maple, which develop a shallow root system in the landscape regardless of soil type (Gilman and Kane 1990; Wilson 1964) respond best when planted from a root-manipulated, low-profile root ball. Low-profile containers position roots close to the soil surface so that there are no deep roots that have to make their way to the landscape soil surface to proliferate. Roots at the bottom of a traditionally shaped container (about as tall as they are wide) would have to grow up to near the soil surface before they proliferate; this could be the reason why trees from three of the five standard dimensioned containers grew slowest.

On the other hand, live oaks (Quercus virginiana L.) planted from low-profile air root-pruning containers grew similar to trees planted from three other deeper container types in the 30 months following landscape installation (Gilman 2001). Perhaps drought-tolerant trees capable of deep rooting, such as live oak, do not benefit by planting 


\section{Table 1. Trunk cross-sectional area of Acer rubrum produced in seven container types after 5 years in the landscape ${ }^{z}$.}

\begin{tabular}{ll}
\hline Container type & Trunk cross-sectional area $\left(\mathrm{cm}^{2}\right)$ \\
\hline SBPC & $158 \mathrm{abc}^{\mathrm{y}}$ \\
Copper-coated SBPC & $140 \mathrm{bc}$ \\
Low-profile BPC $^{\mathrm{w}}$ & $167 \mathrm{abc}$ \\
ARPC $^{\mathrm{v}}$ & $117 \mathrm{bc}$ \\
Low-profile ARPC & $222 \mathrm{a}$ \\
Wooden box & $178 \mathrm{ab}$ \\
Copper-coated wooden box & $105 \mathrm{c}$ \\
\hline
\end{tabular}

${ }^{z}$ Average trunk cross-sectional area at planting $=11.9 \mathrm{~cm}^{2}$.

y Numbers followed by the same letter are not significantly different at $\alpha=0.05$.

${ }^{x} \mathrm{SBPC}=$ standard black plastic container.

${ }^{\mathrm{W} B P C}=$ black plastic container

${ }^{\mathrm{v}} \mathrm{ARPC}=$ air root-pruning container

from low-profile containers because roots that are at the bottom of the traditional container can simply grow into the deeper layers of landscape soil (Marshall and Gilman 1997).

Despite significant differences in root weight and amount of deflected roots among container types when trees were planted (Marshall and Gilman 1998), root number, distribution of roots among depth classes, and number of 45-degree sections around the trunk without roots (radial root distribution) were identical 5 years after planting from all container types. Although no method of evaluating root deformations (circling and kinked roots) on these trees was devised, there appeared to be little difference among container types in the quality of the root systems. Many roots appeared to be adventitious in nature, emerging either from the trunk base or emerging near the trunk from existing main roots after trees were planted in the landscape. These grew more or less from the root flare straight out from the trunk into the landscape just under the soil surface without defects because they were generated after the trees were planted into the landscape. Some may also have emerged behind the kinked or circling portion of the roots. Adventitious root formation above circling roots in red maple has been reported previously (Gilman and Kane 1990). It is unknown whether trees lacking the capability of developing adventitious roots will respond similarly. Perhaps older trees or trees that were more rootbound than the ones used in this study would have responded differently. Our trees were $3.9 \mathrm{~cm}$ caliper whereas industry standards allow up to $5 \mathrm{~cm}$ caliper in \#15 containers (AAN 1996). Some deflected roots appeared to be grafted to other roots of the same tree.

Practitioners report that roots circling the trunk as a result of deep planting can girdle the trunk, causing the tree to slowly decline, or the tree may blow over due to poor root distribution around the trunk (Johnson and Hauer 2000). Perhaps the small diameter (up to $6 \mathrm{~mm}$ ) of the circling roots on the 2-year-old \#15 container size trees used in this study was not sufficient to result in permanent root deformation 5 years later. Older trees might have set more of their permanent adventitious roots while in the container. If the permanent roots were initiated in the container instead of in the landscape, there may be a greater chance of deformed root system affecting growth or stability.

Frequency of irrigation in the first 24 weeks following landscape installation had a more discernible $(\mathrm{P}<0.05)$ effect on red maple root system structure 5 years later than did container type. Frequently irrigated trees grew significantly larger trunk cross-sectional area $\left(175 \mathrm{~cm}^{2}\right)$ than infrequently irrigated trees $\left(137 \mathrm{~cm}^{2}\right)$. This finding contrasts with long-term growth on live oak, which was not affected by irrigation applied only in the months following planting (Marshall and Gilman 1997). Perhaps trees tolerant of wet sites, such as red maple, are more responsive to irrigation in the months following planting than more drought-tolerant trees such as live oak. Codominant stems in red maples 4 years after planting were equally common regardless of irrigation treatment (data not shown).

The number of roots 5 years after landscape planting that were less than $40 \mathrm{~mm}$ diameter and root cross-sectional area (all root sizes combined) in the top $30 \mathrm{~cm}$ of soil were both greater in trees irrigated more frequently (Table 2), even though irrigation treatments were discontinued 4.5 years earlier. At the deeper soil depths, there were no differences in root growth (number and cross-sectional area) between irrigation treatments. Large roots ( $>40 \mathrm{~mm}$ diameter) were not affected by irrigation treatment. A shallower root system developed on burford holly (Ilex cornuta 'Burfordii'), a shrub, planted into a landscape, when they were irrigated every 1 to 4 days compared to those irrigated every 10 to 14 days (Gilman et al. 1996b). The current study showed that irrigating red maple trees frequently after landscape installation resulted in enhanced root growth in the shallow soil depths compared to irrigating infrequently. Green and Watson (1989) also found enhanced sugar maple (Acer saccharum L.) root growth in the shallow depths when conditions were improved for root growth with application of mulch to the soil surface.

Red maple trees frequently irrigated during the 24 weeks after planting generated twice the root system weight into the landscape soil in the first 5 months after planting (Marshall and Gilman 1998). By 5 years after planting, trees frequently irrigated had about $50 \%$ more root crosssectional area than those that received infrequent irrigation after planting, even though both treatments received the same rainfall and irrigation for the last 4.5 years (Table 2). Marshall and Gilman (1997) showed greater root number on frequently irrigated container grown live oak trees 3 years after landscape installation compared to those that received infrequent irrigation, but they found no difference 
in root cross sectional area. Fabiao et al. (1995) found that irrigation increased belowground biomass several years after planting, but the effect disappeared after 6 years. Perhaps that effect was occurring for the red maple trees in this study.

Deeper roots proliferated in the infrequent irrigation treatment (about 30\% of the total number of roots were more than $30 \mathrm{~cm}$ deep compared to $16 \%$ for frequently irrigated trees), probably due to lack of sufficient soil moisture closer to the surface (Table 2). The trunk cross-sectional area may have been smaller for infrequently irrigated trees because roots were forced to grow at deeper soil layers.

The number of 45-degree sections containing no roots was greater $(\mathrm{P}<0.05)$ for trees irrigated less frequently $(1.4$ per tree) than for those receiving frequent irrigation $(0.7$ per tree). This finding indicates that frequent irrigation in the first 24 weeks following planting resulted in a more uniform radial root distribution. Large spaces around the trunk lacking roots could increase the chances for tree failure later as it grows taller (Nichols and Alm 1983), but it is not known whether the gaps associated with infrequent irrigation in this study were large enough to meaningfully affect tree stability.

This study indicated that red maple irrigated infrequently the first 24 weeks after planting developed less trunk growth and less of a root system 5 years after planting compared to trees that received frequent irrigation. Regular irrigation in the 24 weeks after landscape planting provided for a doubling of root growth 5 months after landscape planting (Marshall and Gilman 1998). The current study showed that about half of this increase persisted 5 years later and trunks were 35\% larger. Red maple trees in container types such as the low-profile air root-pruning container may be better suited for planting in landscapes than red maples from some other container types. With the exception of the low-profile air root-pruned container, the reduction in root defects on the outer surface of root balls grown in containers designed to reduce defects appeared to provide no measurable benefit to trees 5 months or 5 years after planting into the landscape. Irrigation management after planting had a more positive impact on landscape root growth and distribution than container type.

Irrigation management in the months after planting had a large impact on live oak survival (Gilman 2001; Gilman et al. 1996a) but little impact on long-term top growth of surviving trees, probably because site factors control growth rate once trees are established. For red maple installed into a landscape in spring in the southeast United States from \#15 containers, irrigating with 38 L once a day for 7 days then every third day for 2 months, then 3 times a month for 3 months appears to establish trees successfully with $100 \%$ survival, but they grow slower than trees more frequently irrigated during the first 24 weeks after planting. The growth-enhancement effects of irrigation in the 24 weeks after planting still remained 5 years after planting, even though irrigation treatments were discontinued 4.5 years earlier. Irrigation needs to be applied only to the root ball and to a small area around the root ball after planting for $100 \%$ survival.

Table 2. Number of roots 5 years after planting of different diameter size classes and total root cross-sectional area at three depths below the soil surface on Acer rubrum irrigated frequently or infrequently in the first 24 weeks after landscape planting.

\begin{tabular}{|c|c|c|c|c|c|c|}
\hline Irrigation frequency & $\begin{array}{l}\text { Soil } \\
\text { depth }(\mathrm{cm})\end{array}$ & $\begin{array}{l}\text { No. of roots } \\
<20 \mathrm{~mm} \\
\text { diameter }\end{array}$ & $\begin{array}{l}\text { No. of roots } \\
20 \text { to } 40 \mathrm{~mm} \\
\text { diameter }\end{array}$ & $\begin{array}{l}\text { No. of roots } \\
>40 \mathrm{~mm} \\
\text { diameter }\end{array}$ & $\begin{array}{l}\text { Total no. } \\
\text { of roots }\end{array}$ & $\begin{array}{l}\text { Total } \\
\text { root cross- } \\
\text { sectional } \\
\text { area }\left(\mathrm{cm}^{2}\right)\end{array}$ \\
\hline Frequent $t^{2}$ & $<30$ & 24.2 & 11.2 & 1.5 & 37.0 & 140.1 \\
\hline Frequent & 30 to 60 & 3.0 & 0.5 & 0.1 & 3.6 & 8.2 \\
\hline Frequent & $>60$ & 1.4 & 0.6 & 0.1 & 2.1 & 7.5 \\
\hline Infrequent ${ }^{y}$ & $<30$ & 13.9 & 6.7 & 0.8 & 21.3 & 74.9 \\
\hline Infrequent & 30 to 60 & 3.3 & 0.9 & 0.2 & 4.5 & 14.1 \\
\hline \multirow[t]{2}{*}{ Infrequent } & $>60$ & 4.6 & 1.1 & 0.2 & 5.9 & 15.5 \\
\hline & & \multicolumn{5}{|c|}{ Significance of treatment effects at $\alpha=0.05$} \\
\hline Soil depth & & * & $*$ & $*$ & $*$ & $*$ \\
\hline Irrigation frequency & & * & NS & NS & * & NS \\
\hline \multirow[t]{2}{*}{ Soil depth $\mathrm{x}$ irrigation frequency } & & $*$ & $*$ & NS & * & $*$ \\
\hline & & & & Contrasts & & \\
\hline Frequent vs. infrequent $<30 \mathrm{~cm}$ depth & & $*$ & $*$ & NS & $*$ & $*$ \\
\hline Frequent vs. infrequent 30 to $60 \mathrm{~cm}$ depth & & NS & NS & NS & NS & NS \\
\hline Frequent vs. infrequent $>60 \mathrm{~cm}$ depth & & NS & NS & NS & NS & NS \\
\hline
\end{tabular}

${ }^{2}$ Frequent $=37.8 \mathrm{~L}$ applied daily for 9 weeks, then every other day through week 24 .

'Infrequent $=37.8 \mathrm{~L}$ applied daily for 1 week, once in weeks 2 and 3, every third day weeks 4 through 9, every 10 days weeks 10 through 19 .

${ }^{*}$ Effect is significant at $\alpha=0.05$. 


\section{LITERATURE CITED}

American Association of Nurserymen (AAN). 1996. American Standard for Nursery Stock, Z60.1. American National Standards Institute, Washington DC.

Arnold, M.A. 1996. Mechanical correction and mechanical avoidance of circling roots differentially affect posttransplant root regeneration and field establishment on container-grown shumard oak. J. Am. Soc. Hortic. Sci. 121:258263.

Arnold, M.A., and D.K. Struve. 1993. Root distribution and mineral uptake of coarse-rooted trees grown in cupric hydroxide-treated containers. HortScience 28:988-992.

Beeson, R.C., Jr. and R. Newton. 1992. Shoot and root responses of eighteen southeastern woody landscape species grown in cupric hydroxide-treated containers. J. Environ. Hortic. 10:214-217.

Brass, T.J., G.J. Keever, D.J. Eakes, and C.H. Gilliam. 1996. Styrene-lined and copper-coated containers affect production and landscape establishment of red maple. HortScience 31:353-356.

Fabiao, A., M. Madeira, E. Steen, T. Katterer, C. Ribeiro, and C. Araujo. 1995. Development of root biomass in a Eucalyptus globulus plantation under different water and nutrient regimes. Plant Soil 168-169:215-223.

Gilman, E.F. 2001. Effect of nursery production method, irrigation, and inoculation with mycorrhizae-forming fungi on establishment of Quercus virginiana. J. Arboric. 27:30-39.

Gilman, E. F., and M.E. Kane. 1990. Root growth of red maple following planting from containers. HortScience 25:527-528.

Gilman, E.F., R.J. Black, and B. Dehgan. 1996a. Irrigation volume and frequency and tree size affect establishment rate. J. Arboric. 24:1-9.

Gilman, E.F., T.H. Yeager, and D. Weigle. 1996b. Fertilization, irrigation and root ball slicing affects burford holly growth after planting. J. Environ. Hortic. 14:105-110.

Green T.L., and G.W. Watson. 1989. Effects of turfgrass and mulch on the establishment and growth of bare-root sugar maple. J. Arboric. 15:268-272.

Johnson, G.R., and R.J. Hauer. 2000. A practitioners guide to stem girdling roots. University of Minnesota Extension Publication BU-7501-S.

Marler, T.E., and D. Willis. 1996. Chemical or air-root pruning containers improve carambola, longam, and mango seedling root morphology and initial root growth after planting. J. Environ. Hortic. 14:81-87.
Marshall, M.D., and E.F. Gilman. 1997. Production method and irrigation affect root morphology of live oak. J. Environ. Hortic. 15:84-87. 1998. Effects of nursery container type on root growth and landscape establishment of Acer rubrum L. J. Environ. Hortic. 15:55-59.

Martin, C.A., and S. Bhattacharya. 1995. Effects of cupric hydroxide treated containers on growth of four southwestern desert landscape trees. J. Arboric. 21:235238.

Nichols, T.J., and A.A. Alm. 1983. Root development of container-reared, nursery-grown and naturally regenerated pine seedlings. Can. J. For. Res. 13:239-245.

Privett, D.W., and R.L. Hummel. 1992. Root and shoot growth of 'Coral Beauty' cotoneaster and Leyland cypress produced in porous and nonporous containers. J. Environ. Hortic. 10:133-136.

SAS Institute, Inc. 1992. SAS/STAT Users Guide. SAS Institute, Inc., Cary, NC.

Struve, D.K., M.A. Arnold, R.C. Beeson, Jr., J.M. Ruter, S. Svenson, and W. Witte. 1994. The copper connection. Am. Nurserymen 179:52-56.

Warren, S.L., and F.A. Blazich. 1991. Influence of container design on root circling, top growth, and post-transplant root growth of selected landscape species. J. Environ. Hortic. 9:141-144.

Wilson, W.F. 1964. Structure and growth of woody roots of Acer rubrum L. Harvard Forest Paper No. 11. Petersham, MA.

Acknowledgments. Thanks to Marshall Tree Farm, Morriston, Florida, for providing the 80-inch tree spade and personnel for digging trees. Florida Agricultural Experiment Station Journal Series number R-09271.

*Department of Environmental Horticulture

University of Florida

Gainesville, FL 32611, U.S.

*Corresponding author: Edward F. Gilman 
Résumé. Lobjectif de cette recherche était de comparer la croissance des racines et de la cime de l'érable rouge (Acer rubrum L.) sur une période de cinq ans après la plantation, et ce à partir de plants produits dans sept types différents de contenants et deux régimes différents d'irrigation. Les arbres plantés à partir de contenants à profil bas pour la taille aérienne des racines avaient des troncs plus gros cinq ans après leur mise en terre, et ce par rapport à ceux produits en contenants réguliers pour la taille aérienne des racines, ceux en boîtes de bois avec un enduit d'hydroxyde cuprique, ou encore ceux en contenants standards en plastique noir avec un enduit d'hydroxyde cuprique. En dépit des différences significatives dans la masse racinaire et la quantité de racines en spirales parmi les différents types de contenants lorsque les arbres étaient plantés sur le site, la quantité de racines, la profondeur et la distribution radiale autour du tronc de ces dernières étaient identiques cinq ans après la plantation, et ce pour tous les types de contenants. Néanmoins, la fréquence de l'irrigation dans les 24 premières semaines après la mise en terre avait un impact significatif sur la structure du système racinaire, et même cinq ans après. Une irrigation fréquente résulte en des troncs plus gros, plus de racines, une plus grande surface racinaire en coupe transversale ainsi qu'une distribution radiale en racines plus uniforme. Pour les arbres fréquemment irrigués, l'augmentation en croissance racinaire se produisait exclusivement dans les 30,5 premiers centimètres de sol. Les tiges codominantes étaient équivalentes entre elles quatre ans après la plantation, peu importe la méthode de production et le type d'irrigation. À l'exception du contenant à profil bas pour la taille aérienne des racines, la diminution en défauts chez les racines avec des contenants conçus pour réduire ce type de défauts, et ce au-dessus de la surface de la motte de racines, n'apparaissait pas se concrétiser en résultats positifs mesurables cinq mois ou cinq ans après la plantation. La gestion de l'irrigation après la plantation avait un impact plus positif sur le développement des racines et sur leur distribution après la plantation que le type de contenant de production.

Zusammenfassung. Das Ziel dieser Studie war, das Wachstum von Wurzel- und Kronenwachstum von Rotahorn nach 5 Jahren des Auspflanzens aus 7 verschiedenen Kulturformen unter 2 verschiedenen Bewässerungssystem zu vergleichen. Die Bäume aus einem Niedrigprofilcontainer hatten nach 5 Jahren größere Stämme als als die Bäume aus regulären Containern, Holzboxen mit Kupferoxidüberzug oder Standardcontainer mit Kupferoxidüberzug. Ungeachtet deutlicher Unterschiede im Wurzelgewicht und der Menge an angelenkten Wurzeln zwischen anderen Containertypen, wenn die Bäume ins Freiland verpflanzt wurden, war die Wurzelanzahl, -tiefe und radiale Verteilung um den Stamm fünf Jahre nach der Verpflanzung bei allen Containerpflanzen gleich. Trotzdem hatte die Bewässerungsfrequenz in den ersten 24 Wochen nach der Verpflanzung auch nach 5 Jahren einen deutlichen Einfluß auf das Stammwachstum. Regelmäßige Bewässerung führte zu stärkeren Stämmen, mehr Wurzeln, größerem Wurzeldurchmesser und einer gleichmäßigeren Wurzelverteilung. Die Zunahme des Wurzelwachstums von regelmäßig bewässerten Bäumen trat ausschließlich in den oberen $30 \mathrm{~cm}$ Boden auf. 4 Jahre nach der Pflanzung zogen die Kodominanten Stämmlinge gleich, unabhängig von der Produktions- oder Bewässerungsmethode. Mit Ausnahme der Niedrigprofilcontainer, konnte die Reduktion der Wurzeldefekte auf dem äußeren Wurzelballen keinen messbaren Vorteil für die Bäume nach 5 Monaten oder 5 Jahren nach der Verpflanzung in die Landschaft bringen. Das Bewässerungsmanagement nach der Pflanzung hatte mehr positive Einflüsse auf die Wurzelverteilung und das Wachstum als der Containertyp.

Resumen. El objetivo de esta investigación fue comparar el crecimiento de las raíces de maple rojo (Acer rubrum L.) y el crecimiento de la copa, cinco años después de la plantación, en siete diferentes diseños de contenedores mantenidos bajo dos regímenes de riego. Los árboles plantados en contenedores con poda de raíz tuvieron troncos más grandes cinco años después de la instalación, que los plantados en contenedores regulares (cajas de madera con una capa de hidróxido de cobre). A pesar de las diferencias significativas en el peso de las raíces y cantidad de raíces deflectadas entre los tipos de contenedores, cuando los árboles fueron plantados en el terreno, el número, profundidad y distribución radial de las raíces alrededor del tronco fueron idénticas, cinco años después de la plantación en todos los tipos de contenedores. Sin embargo, cinco años después, la frecuencia del riego en las primeras 24 semanas siguientes a la plantación tuvo un significante efecto en la estructura del sistema de raíces. La frecuencia del riego resultó en troncos grandes, más raíces, mayor área transversal de las mismas, y una mayor distribución radial. El incremento en el crecimiento de las raíces sobre la frecuencia de los árboles regados ocurrió exclusivamente en la parte superior de $30.5 \mathrm{~cm}$ de suelo. Cuatro años después de la plantación, los tallos codominantes fueron igualmente comunes sin importar el método de producción y el tratamiento de riego. Con la excepción de los contenedores de poda de raíces, la reducción en los defectos de las raíces en la superficie exterior de la bola del cepellón, no produjo beneficios mensurables cinco años después de la plantación. El manejo del riego después de la plantación tuvo un impacto positivo en el crecimiento y en la distribución de las raíces, mejor que el tipo de contenedor. 